\title{
FIQIH DAKWAH DALAM KISAH-KISAH SURAT AL-KAHFI
}

\author{
Oleh: Mohammad Bashri Asyari ${ }^{1}$
}

\begin{abstract}
Da'wah on the basis of inviting humans back to their original nature, accepts the oneness and divinity of Allah $S W T$. This task is not only mandated for the Prophets and Apostles, but is mandated for humanity who have believed in Him. The stories translated in Surat al-Kahf with the preachers of non-Prophets and Apostles, are the best examples of devotees who support the exploration of preaching that need to be explored by instructions, lessons and substantive messages to be spoken and practiced at this time. This limits the research studies on the verses on the four stories in Surat al-Kahf which contain the essence of the fiqh of da'wah, and does not discuss the details of the stories because this has been extensively studied and discussed in classic or modern commentary books.
\end{abstract}

Keywords: Fiqih of Dakwah, Stories, Surat al- Kahfi

Abstrak: Dakwah pada hakikatnya mengajak manusia kembali ke fitrah asalnya, mengakui keesaan dan ketuhanan Allah Swt. Tugas ini tidak hanya diamanahkan kepada para Nabi dan Rasul, tetapi diamanahkan kepada seluruh umat manusia yang telah beriman kepada-Nya. Kisah-kisah yang ditampilkan dalam Surat al-Kahfi dengan para da'i non Nabi dan Rasul, merupakan contoh terbaik dari umat terdahulu dalam menjalankan kewajiban berdakwah yang perlu dieksplorasi petunjuk, pelajaran dan pesanpesan substansialnya untuk di rekonstruksi dan dipraktikkan pada masa ini. Penelitian ini membatasi kajiannya pada ayat-ayat pada keempat kisah dalam Surat al-Kahfi yang memuat esensi fiqih dakwah, dan tidak membahas rincian kisah-kisahnya karena hal ini sudah banyak diteliti dan dibahas dalam buku-buku tafsir klasik atau modern.

Kata Kunci: Fiqih dakwah, Kisah-Kisah, Surat al-Kahfi

\section{A. Pendahuluan}

Surat al-Kahfi merupakan salah satu surat yang memuat pengalamanan umat terdahulu yang dikemas melalui kisah-kisah dan dialog yang

\footnotetext{
${ }^{1}$ Mohammad Bashri Asyari merupakan Dosen Institut Agama Islam Negeri (IAIN) Madura. Email:bashri2 $\overline{5}$ gmail.com

188| Mohammad Bashri Asyari
} 
bervariasi. Surat ini memuat empat kisah yang cukup menarik untuk diteliti, karena memuat cerita empat segmen da'i yang berbeda untuk empat segmen mad' $\bar{u}$ yang berbeda pula. Kisah Ashab al-Kahfi, mewakili segmen anak muda yang menjadi agent of the change terhadap masyarakatnya, Ashab al-Jannataini (pemilik dua kebun) mewakili kaum profesionalis, sementara Khidhir dan Musa as. mewakili kaum intelektual, dan Dzul Qarnain mewakili kaum birokrat.

Dilihat dari urutan kiasah-kisahnya, surat ini memberikan harapan dan optimis yang besar kepada Nabi Muhammad Saw. dan sahabat-sahabat beliau bahwa pada akhirnya dakwah yang mereka lakukan tidak akan terhenti pada fase sulit dan stagnan seperti dakwah pada masa Ashab alKahfi, tetapi dapat juga dengan izin Allah Swt. akan berkembang dari kondisi yang tidak baik menjadi baik sebagaimana pada kisah Ashāb aljannatain. Pada masanya dakwah dapat dilakukan secara terbuka dan tanpa hambatan psikologis antara mukmin dan mukmin.

Kemudian dakwah semakin berkembang dengan adanya konsolidasi para $d a ' i$ dan transfer pengalaman dalam menangani persoalan umat yang ditampilkan dalam kisah Nabi Musa dan Khidir As. Kondisi dakwah terus berkembang dan mencapai puncak keberhasilannya yang ditampilkan pada kisah Dzulqarnain. Pada masanya, dakwah menyatu dengan kekuatan politik sehingga nilai-nilai ajaran agama dalam kehidupan masyarakat dapat ditranformasikan dengan leluasa dan dirasakan sebagai rahmat yang luar biasa. Kondisi dakwah pada masa Dzulqarnain sama dengan kondisi dakwah Rasulullah saw. pada periode dakwah di Madinah. Oleh karenanya, Surat alKahfi sunnah dibaca setiap hari Jum'at sebagai suplai energi bagi kaum Muslimin untuk mengingat dan kosisten terhadap komitmennya dalam mendakwahkan ajaran Islam sesuai dengan kapasitas masing-masing agar mampu mengulang sejarah kesuksesan pendahulunya.

Penelitian ini diharapkan dapat memberikan kontribusi kepada para da'i dan lembaga dakwah dan akademisi dalam memetakan prolematika dakwah yang terjadi dalam sebuah komunitas, potensi dan kemampuan mempergunakan metode yang tepat dan efektif dalam mentransformasikan ajaran Islam sehingga mampu melakukan perubahan dan perbaikan secara bertahap namun pasti, dari lemah menjadi setara, dan dari setara menjadi kekuatan yang solid dan akhirnya menjadi pemenang dan pewaris ajaran 
Islam yang menjadi rahmat untuk seluruh manusia, menjadi saksi sejarah pengulangan kejayaan Islam di masa lalu.

Di samping itu pula untuk menyuguhkan penjelasan yang lebih komprehensif dalam penelitian ini, penulis mengelaborasi dengan berbagai penelitian tentang Surat al-Kahfi dengan fokus kajian yang beragam, seperti:

1. Penelitian dilakukan oleh 'Athiyah Zâhidah dengan judul:"Manhaj Tajdiydiy fi al-Tafsir Ahlu al-Kahfi fi Qamaran Namûdzajan, dipresentasikan dalam seminar international kajian I'jaz al-Qur'an di Malaysia. Peneliti mengkaji penafsiran pembaharuan Mushthafa al-Siba'i tentang kemu'jizatan jumlah huruf yang dimuat dalam ayat-ayat cerita Ashab al-Kahfi yang mencerminkan angka 18 dan merupakan kelipatan angka 9.

2. Penelitian dilakukan oleh Muhammad Adnan Ali al-Qudhat dengan judul:" Mafhūm al-Hiwār fi al-Qur'ân wa in'ikāsātuhū alTarbawiyyah". Penelitiannya ditekankan pada metode dialog dalam Surat al-Kahfi dan fungsinya dalam menetapkan wujud Allah, alQur'an bersumber dari Allah, pengukuhan para rasul dan nilai-nilai kehidupan dunia dan akhirat serta implikasinya terhadap pendidikan.

3. Zuhdî Muhammad Abu Nikmah dengan judul:" As-Syakhshiyyat alIjabiyah fi Surati al-Kahfi,(juli,2007). Penelitian ini membahas tentang prilaku positif yang diambil dari pelaku kisah dalam Surat al-Kahfi. Indikatornya Terpanggil nuraninya untuk membangun kesadaran umatnya, berkhidmat untuk memajukan dan meninggikan martabat mereka dan sikap positif lainnya.

Dari penelitian terdahulu belum ada yang mengkaji Kisah-Kisah dalam Surat al-Kahfi dari sudut pandang fiqih dakwah secara komprehensip. Akan tetapi isi dan muatan penelitian terdahulu sangat berharga dalam memperkaya wawasan dalam mengeksplorasi lebih mendalam tentang fiqih dakwah yang dimuat dalam keempat kisah tersebut.

\section{B. Metode Penelitian}

Penelitian ini merupakan penelitian kualitatif pustaka dengan pendekatan deskriptif analitik dan tergolong sebagai model penelitian 
library reseach. Adapun objek penelitian ini terfokus pada studi fiqh dakwah dalam kisah-kisah Surat al-Kahfi.

Sumber data dari penelitian ini berupa sumber tertulis yang terdiri darial-Qur'an in word, buku-buku tafsir, ulum al-Qur'an, Sirah Nabawiyah, buku- buku ilmu dakwah, tulisan-tulisan yang terkait dengan dengan pembahasan ini. Dari data ini kemudian penulis menganalisisnya dengan metode deskripsi, interpretasi dan induktif-dedukti-komparatif. Analisis data dengan metode deskripsi adalah menguraikan secara teratur mengenai fiqh dakwah dalam Surat al-Kahfi dengan bantuan penafsiran para mufassir baik klasik dan kontemporer serta para pakar dakwah kontemporer.

Dalam hal ini, peneliti tidak membuat interpolasi, uraian atau memasukkan asumsi-asumsi pribadi yang dapat mereduksi interpretasi mereka. ${ }^{2}$ Kemudian penulis menggunakan analis data dengan interpretasi yakni peneliti melakukan telaah terhadap interpretasi para mufassir dan para peneliti dan memgambil kesimpulan, kemudian mengambil esensinya yang menjadi tujuan kajian. Jadi dalam hal ini peneliti tidak hanya memahami suatu interpretasi seperti apa adanya, tetapi lebih kepada tekanan tema-tema fiqh dakwah yang menjadi benang merah antara kisahkisah dalam Surat al-Kahfi. Karenanya, dalam menganalisa data yang ada, peneliti akan melihat adanya kemungkinan-kemungkinan lain dari hasil interpretasi para mufassir dan para peneliti tentang fiqih dakwah yang dimuat dalam kisah-kisah tersebut.

Terakhir penulis menggunakan analisis data dengan metode deduktif digunakan dalam rangka memahami detail-detail pandangan para mufassir dan para pakar dakwah kontemporer dalam menafsirkan ayat-ayat dalam keempat kisah dalam Surat al-Kahfi tentang fiqhi dakwah. Sedangkan metode induktif digunakan untuk mendapatkan pandangan yang utuh dan seimbang dari penafsiran dan hasil telaah mereka. Sementara metode komparatif digunakan untuk membandingkan penafsiran para mufassir dan para pakar dakwah kontemporer untuk mendapatkan penafsiran yang lebih mendalam, relevan dan aplikatif. ${ }^{3}$

\section{Pembahasan}

\footnotetext{
${ }^{2}$ Anton Bakker,Achmad Harris Zubair, Metodologi Penelitian Filsafat, (Yogyakaarta: Kanisius,1990), hlm. 76.

${ }^{3 .}$ Ibid,hlm. 86-87.
} 
Dari hasil penelusuran pendapat para mufassir dan pakar dakwah berdasarkan rumusan masalah dalam penelitian ini, dapat ditarik benang merah fiqih dakwah berikut:

\section{Prolematika Dakwah dalam Kisah-Kisah Surat al-Kahfi}

Problematika dakwah yang digambarkan dan dihadapi oleh para da' $i$ sangat variatif sesuai situasi dan kondisi masyarakat yang menjadi sasaran dakwah mereka. Ashab al-Kahfi menghadapi penolakan misi dakwahnya dari mayoritas masyarakat yang didukung oleh kekuasaan yang dzalim dan represif sehingga terpaksa menyingkir ke gua untuk mempertahakan agamanya. Kasus ini sama dengan yang dihadapi oleh Nabi Muhammad saw. pada periode dakwah Makkiyyah. Dakwah dihalang-halangi dan kaum muslimin disiksa dan disakiti sehingga sebagian hijrah ke Kota Habsyah, dan sebagaian besar hijrah ke Kota Yatsrib.

Situasi dan kondisi dakwah seperti ini dapat berulang sepanjang masa walaupun volume risistensinya berbeda. Dalam situasi dan kondisi dakwah seperti ini, para pelaku dakwah dituntut ketahanan akidah yang prima, kesabaran, nyali yang panjang dan bahkan kesiapan mati syahid sebagaimana yang terjadi pada sabahat Yasir ra. dan istrinya, Sumayyah, taktik dan strategi dakwah yang sesuai dengan situasi dan kondisinya. Dalam hal ini, metode dakwah yang layak dipergunakan adalah dakwah sirriyah dengan strategi dakwah individual sesuai dengan kapasitas dan segmentasi masyarakat di lingkungan da'i masing-masing .

Pada Kisah Ashab al-Jannatain, harta dan status sosial dapat menjadi pemicu dan pendorong seseorang lalai dan lupa diri sampai pada taraf kekufuruan, dan menjadi penyokong kekufuran. Penyakit lupa diri merupakan penyebab tertutupnya kebenaran dalam hati dan akal serta penghalang masuknya cahaya kebenaran ke dalam hati ${ }^{4}$ sebagaimana firman-Nya dalam Surat al-Kahfi:57:
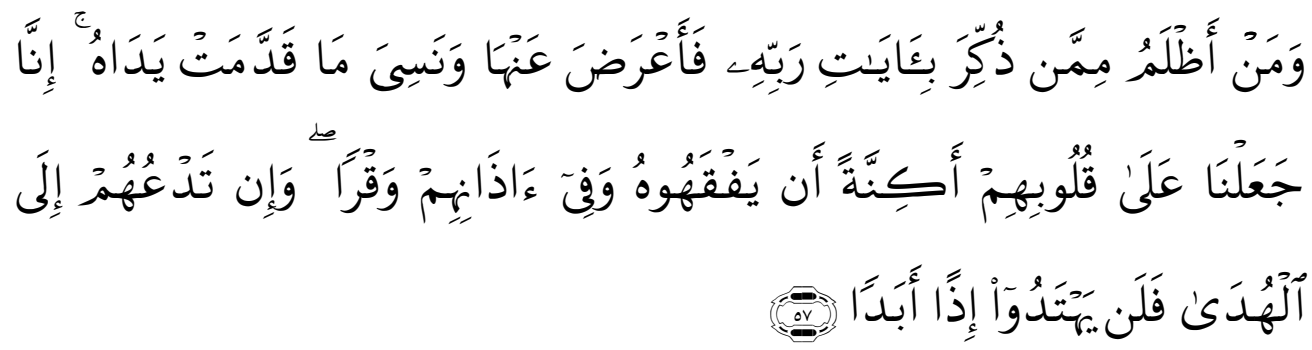

\footnotetext{
${ }^{4}$ Muhammad Adi lal-Qalqili, al-Handasah al-Ilahiyah fi Surati al-Kahfi, hlm.,17.
} 
Artinya:"Dan siapakah yang lebih zalim dari pada orang yang Telah diperingatkan dengan ayat-ayat Tuhannya lalu dia berpaling dari padanya dan melupakan apa yang Telah dikerjakan oleh kedua tangannya? Sesungguhnya kami Telah meletakkan tutupan di atas hati mereka, (sehingga mereka tidak) memahaminya, dan (Kami letakkan pula) sumbatan di telinga mereka; dan kendatipun kamu menyeru mereka kepada petunjuk, niscaya mereka tidak akan mendapat petunjuk selama-lamanya".

Para Nabi terdahulu selalu menghadapi kelompok masyarakat sejenis ini yang disebut al-Qur'an dengan panggilan :" al-Mala' “. Qarun merupakan salah satu contoh dari sekian kelompok masyarakat jenis ini yang aktif membela kekufuran. Kelompok masyarakat jenis ini dapat berubah dan menjadi penyangga kebenaran dan dakwah, jika mampu direkrut seperti yang terjadi pada diri Umar bin Khaththab dan Hamzah ibn Abi Thālib ra. Nabi Muhammad Saw. bersabda: خياركم فى الجاهلية خياركم ( Orang yang terbaik di antara kalian pada masa jahiliyah akan menjadi yang terbaik pada masa ia memeluk Islam, jika mereka memahami (Islam) secara mendalam).

Pada Kisah Khidir dan Musa as. problem yang hadapi Khidir as. mentrasfer ilmu yang tidak dimiliki oleh Nabi Musa as., dan jenis ilmu keduanya berbeda sehingga berpotensi terjadinya perbedaan dalam menangani persoalan dakwah di lapangan sebagaimana yang benar-benar terjadi dalam kisah keduanya. Pada kondisi yang seperti ini, seharusnya seorang da'i bersikap percaya diri dengan keilmuan yang dimiliki dan perlu mengadakan kontrak belajar/kesepakatan dalam menstranfer ilmu dan pengalaman kepada mitranya. Kisah ini memberi pelajaran kepada para da'i untuk saling tukar menukar pengalaman, menambah wawasan keilmuan dan kearifan dalam mengatasi perbedaaan pendapat dan teknis mengangani kasus-kasus di lapangan selama tujuan akhirnya bertemu pada titik yang sama, serta berkonsilidasi dalam memajukan dakwah menuju titik final kesempurnaannya.

Pada Kisah Dzulqarnain, dakwah sudah mencapai usia kematangan dan kekuasaan sehingga dapat mengembangkan dakwah dan memantapkan eksistensinya. Tak ada lagi kendala dalam menyampaikan dakwah sebagaimana pada masa Ashab al-Kahfi yang menghadapi penguasa yang dzalim, yang ada bagaimana kekuasaan itu dipergunakan untuk mengekselearasi dakwah sehingga mampu menjangkau seluruh penjuru 
dunia dan mampu dengan mudah menyelesaikan berbagai persoalan yang dihadapi umatnya. Pada safari dakwah pertama dan kedua, problem yang dihadapi masyarakatnya sama. Mereka memusyrikkan Allah SWT. dan belum tersentuh dakwah tauhid, sementara pada safari dakwah ketiga, masyarakat yang ditemukannya menyambut kedatangan Dzulqarnain dan bala tentaranya dengan baik yang indikatornya mereka menyampaikan permohonan untuk membangun tembok sebagai upaya membendung kedaliman Ya'jüj dan Ma'jūj.

Para Da'i yang memperoleh kekuasaan, memiliki sarana dan akses untuk melayani umat, seharusnya tidak menunggu laporan problem umatnya, tetapi harus turun ke bawah melakukan kunjungan kerja nyata untuk melihat realitas problem umatnya agar mampu memberikan pelayanan yang baik dan memberikan solusi yang sesuai dan efektif.

\section{Respon Para Da'i Terhadap Problematika Dakwah dan Solusinya}

Para da'i pada keempat kisah sama-sama tanggap dan sigap merespon persoalan yang dihadapi umatnya masing-masing sesuai perintah agama yang dipeluknya. Para pemuda Ashab al-Kahfi mengahadapi ancaman kekerasaan dan kedzaliman penguasa dengan tenang, berani dan kesabaran yang prima. Ada beberapa faktor pendudukung yang menyebabkan mereka bertahan memeluk dan mendakwahkan keyakinan tauhidnya, Pertama, usia muda, memiliki keimanan yang kuat yang diisyaratkan dalam ayat " wa rabathnā 'ala qulübihim" keberanian yang disyaratkan dalam ayat " idz qāmu ", kepedulian kepada sesama yang diisyaratkan " haula' qaumuna ", kebersamaan yang disyaratkan dengan lafadz plural, dan sikap optimis karena merasa mereka bagian keluarga penguasa sebagaimana disingung dalam sebab nuzul ayat tentang kisah Ashab al-Kahfi.

Sahabat Ashāb al-Jannatain, merespon kesesatan sahabatnya dengan dialog dan nasehat yang konstruktif, membangunkan kesadaran fitrah dengan cara mengingatkan asal muasal penciptaannya. Cara ini sangat ampuh khususnya bagi orang-orang yang sombong dan lupa diri. Dalam banyak peristiwa, Al-Qur'an menggunakan pendekatan ini, seperti pada seseorang yang ingkar terhadap adanya hari kiamat dalam Surat Yasin, alWāqi'ah dan lain-lainnya. 
Pendekatan dengan mempergunakan akses persahabatan, biasanya lebih mudah diterima karena lebih familiar, akrab dan adanya rasa empati yang tidak dimiliki oleh selainnya. Para sabahat Nabi Muhammad saw. mempergunakan pendekatan dakwah ini dan ternyata banyak yang berhasil. Contohnya, Abu bakar ra. yang berhasil mengislamkan Utsman, Abdurrahman bin Auf mitra sahabatnya yang sama-sama berprofesi sebagai pedagang di masanya. Jika dalam kisah Ashab al-Jannatain, sahabatnya tidak berhasil merubah kemusyrikan dan kekufurannya, tidak berarti gagal, karena yang dituntut bagai seorang da'i adalah usahanya yang optimal dan bukan hasilnya.

Dzulqarnain dengan kekuasaan yang dimilikinya dan para pembantunya yang setia dan memiliki kesalehan pribadi sama dengannya, dengan mudah dan cepat merespon persoalan yang ditemukan pada setiap daerah yang menjadi target safari dakwahnya.Kisah ini memberi arahan bahwa tugas utama para da'i yang yang dikaruniai kekuasaan adalah melaksanakan firman Allah SWT. dalam Surat al-Hajj:41. Pertama, mengajak mendirikan shalat dengan menyediakan sarana dan prasarananya, meningkatkan ekonomi rakyatnya sehingga mampu menjadi pembayar zakat yang diisyaratkan dalam potongan ayat "wa $\bar{a} t \bar{u}$ azzakăta, mendorng kebaikan berkembang pesat sebagaimana diisyaratkan dalam penggalan ayat" wa amarū bi al-ma'rüf dan mencegah kemungkaran sehingga kemungkaran sepi pendukung.

\section{Petujuk dan Pesan Dakwah dalam Kisah-Kisah Surat Al-Kahfi}

Petunjuk dan pesan dakwah yang dimuat dalam keempat kisah yang menjadi mata rantai aktivitas dakwah yang terencana dan terukur sehingga mampu menghadirkan hasil yang optimal dapat dijabarkan sebagaimana berikut:

a. Pada keempat kisah, terdapat problem yang sesuai dengan periode dakwah masing-masing. Kisah Ashab al-Kahfi, merepresentasikan periode dakwah awal yang penuh tantangan, sedikit pendukung dan banyak penentangnya, tetapi jumlah pendukung dakwah yang minoritas memiliki militansi yang kuat, tidak pantang menyerah, walau pun harus diusir dari negerinya yang tercinta. Juru dakwah yang menjadi ujung tombaknya rata-rata memiliki usia muda sebagaimana para pengikut dan sahabat Nabi Muhammad Swa. 
Realitas ini seharusnya memberi inspirasi kepada para aktivis dakwah untuk memperiotaskan anak muda sebagai kader-kader aktivis dakwah masa depan.

Ashab al-Jannatain, merepresentasikan periode dakwah terbuka seperti masa orde reformasi di Indonesia kini. Periode ini tidak mungkin terjadi sendirinya, tetapi merupakan hasil jihad panjang para aktivis dakwah. Pada era keterbukaan dakwah ini, seharusnya dakwah dirancang untuk menembus semua segmen masyarakat secara intensif dan masif sehingga jumlah kader-kader aktivis dakwah baik secara kuantitatatif dan kualitatif bertambah dan memiliki keahlian yang variatif untuk menyongsong periode berikutnya. Rasulullah saw. ketika menyadari stagnansi perkembangan dakwah di Makkah, beliau merancang untuk mengembangkannya di luar daerah Kota Makkah, mengutus para sahabat ke Habsyah, mengutus Mush'ab Ibn Umair ke Yatsrib dan beliau sendiri mencoba menjajaki peluang ke daerah Thâif. Beliau menyadari urgensi basis demografis dan geografis sebagai modal menuju kekokohan eksistensi dakwah dan kesempurnaannya. Akhirnya, beliau berhasil menemukan Kota Madinah sebagai kota yang tepat dan pantas menjadi basis perjuangan dakwahnya.

Kisah Khidir dan Musa as. menggambarkan periode dakwah terbuka dan maju dan berhasil memunculkan tokoh-tokoh ulama dan cendikiawan yang memiliki kapasitas keilmuan yang kompeten dan bervariasi. Pertemuan keduanya yang terjadi di dua laut yang berbeda menguatkan perbedaan keilmuan keduanya. Pada periode dakwah seperti ini, yang dibutuhkan adalah konsolidasi para aktivis dakwah, memperkokoh silaturrahim, menyelesaikan perbedaan pemahaman untuk menyatukan langkah, persepsi dan teknis dalam menyelesaikan persoalan umat secara menyeluruh sehingga menjadi kekuatan dan arus besar perubahan dari lemah menjadi kuat dan dari kuat menjadi bersinergi.

Periode Dzuqarnain merepresentasikan periode "tamnkin" ( meraih kekuasan politik). Pada periode ini, dakwah tampak berkembang pesat sama halnya pada periode dakwah Rasulullah saw. di Kota Madinah yang dimulai dari awal hijrah sampai terjadinya perang Khandaq., dan mampu membangun kekuatan yang kokoh 
pasca perjanjian Hudaibiyah hingga wafatnya Rasulullah Saw. Orang-orang Muslim tidak lagi merasa takut untuk diserang musuhmusuhnya dan berubah menjadi orang-orang memiliki jiwa ekspansif اليوم ": sebagaimana pernyataan Rasulullah saw. setelah Perang Ahzab

“ ( pada hari ini kita yang memerangi mereka dan jangan sampai mereka yang memerangi kita) ${ }^{5}$. Pada periode dakwah ini, kekuasaan menyatu dengan dakwah dan dapat mengekselerasi pertumbuhan dakwah karena memiliki sarana dan prasarana yang cukup yang didukung oleh kebebasan membuat kebijakan dan kemampuan mengeksekusinya.

b. Setiap periode memiliki problem yang berbeda yang harus dihadapi oleh aktivis dakwah. Untuk menghadapi problem-problem dakwah diperlukan diperlukan manajemen tata kelola problem dengan cara melakukan inventarisasi problem untuk dicari langkah-langkah solutifnya.

Pada Kisah Ashab al-Kahfi, problem yang dihadapi mereka adalah cara mempertahankan akidah tauhid dihadapan penguasa yang muyrik, dzalim dan dikatator serta tidak segan-segan membunuh, sementara jumlah mereka minim dan tak mampu melwan. Solusi yang ditawarkan al-Qur'an pada kasus ini melakukan 'uzlah (menyingkir) ke gua. 'Uzlah fisik dibenarkan dengan syarat : Tidak ada pendukung kebenaran, adanya sikap rakus yang dita'ati, hawa nafsu yang diikuti, masing-masing individu membanggakan pendapatnya sendiri ${ }^{6}$, dan tak belum terbentuk jama'ah atau organisasi massa muslim yang mampu melindunginya.

Pada kasus Ashhāb al-Jannatain, pemiliknya bangga, menyombongkan diri dan ingkar hari akhirat setelah menyaksikan keindahan kebunnya. Ia mendzalimi dirinya sendiri dan merendahkan temannya. Solusinya, teman yang baik seharusnya memberi nasehat seperti yang diungkap dalam Surat al-Kahfi:39, mengingatkan

\footnotetext{
${ }^{5}$ Munir Muhmmad al-Ghadhban, al-Manhaj al-haraki fi al-Sirah al-Nabawiyyah, Juz I, ( Yordania,maaktabah al-Manar,1984), hlm. 207. Detail-detail karakteristik dakwah pada periode ini dapat dibaca pada halaman:209-426 dan karakteristik dakwah pada periode berikutnya dapat dibaca pada Juz II dari hlm. 5-202.

${ }^{6}$ Hadits riwayat at-Tirmidzi,Al-Jami' as-Shahih, (t.tp: Dar al-Fikr, Kitab Tafsir, Juz IV. tt.hlm.323.
} 
bahwa segala sesuatu itu kehendak Allah, dan tidak perlu iri serta merendahkan diri, tetapi memohon agar Allah memberinya rizki yang lebih baik dari rizki sahabatnya yang sombong .

Pada Kisah Dzuqarnain, Ia dikaruniai kekuasan yang luas dan faktor-faktor pendukungnya, menyaksikan ada rakyat yang dzalim kepada Allah SWT. dan lainnya didzalimi secara fisik oleh tetanggaya. Solusinya sebgaimana digambarkan dalam Surat alKahfi:87, 95-97, mereka yang dzalim kepada Allah diberi pilihan untuk meninggalkan kesyirikan atau diberi sanksi di dunia dan akhirat, dan yang mau memeluk agama tauhid diberi kemudahan dan pahala di akhirat. Sedangkan yang didzalimi, mereka diberi bantuan berupa transfer teknologi dan bangunan fisik untuk membendung kedzaliman tetatangganya. $^{7}$

c. Aktifitas dakwah seharusnya dipikul bersama oleh seluruh lapisan masyarakat dengan segmen yang berbeda dalam segala fase dan periodenya. Ashab al-Kahfi mewakili kaum muda, Sahabat Ashab aljannatain mewakili kaum profesionalis, Khidir as. mewakili kaum intelektual, Dzulqarnain, mewakili kaum birokrat. Dakwah tidak dapat dilakukan oleh satu kelompok masyarakat, tetapi seharusnya melibatkan seluruh segmen masyarakat dengan segala potensi keilmuan yang mereka miliki. Dengan pola yang seperti ini, diharapkan akselerasi dakwah tumbuh dengan pesat, karena menjangkau seluruh lapisan masyarakat, lebih diterima karena memiliki kesamaan emosional dan rasa senasib dan seperjuangan.

d. Pola komunikasi dalam menyampaikan dakwah dengan metode dialog seharusnya bervariasi dan tidak sama antara mad'u/mitra dakwah yang mukmin dan kafir. Dalam dialog antara Dzulqarnain dengan orang yang tidak mau beriman, Ia mendahulukan sanksi akhirat daripada sanksi duniawi (al-Kahfi: 87), sementara ketika berdialog dengan orang-orang yang mau beriman, ia mendahulukan pahala akhirat sebelum menyebut pahala duniawi ( al-Kahfi :88). ${ }^{8}$

e. Dakwah hendaknya dikelola dengan manajemen yang baik, diantara dilakukan berdasarkan prinsip manajemen berikut:

${ }^{7}$ Shalah Sulthan, Manhajiyyāt fi al-Taghyîr fî Sûrati al-Kahfi, ( Mesir: Dar Suthan, 2008), hlm.44-45.

${ }^{8}$ Ibid, hlm.119. 
1) Dialog Ashab al-Kahfi berdialog tentang masa tidur mereka, tetapi tidak sepakat pada satu kesimpulan dan akhirnya mereka menyelasikan persoalan yang realistis dan urgen untuk diselesaikan, yaitu memenuhi kebutuhan makanan dengan mengutus salah seorang mereka dan memberi kewenangan untuk membeli makanan yang enak untuk mereka. (al-Kahfi:190). Demikian halnya dengan dialog antara Ashab al-Jannatain dengan sahabatnya, Musa da Khidir as. serta Dzulqarnain dengan rakayatnya dalam menyelesaikan masalah kekinian mereka.

2) Pembagian kerja yang jelas, seperti pembagian kerja antara Dzulqarnain dengan rakyat yang dibantunya membangun tembok keamanan. Mereka menyiapkan besi dan baja, sementara Dzulqarnain mengolahnya keduanya untuk bahan membangun tembok.

3) Kejelasan akad/transaksi dalam setiap kerjasama dakwah seperti yang terjadi antara Khidir dan Nabi Musa as. dalam belajar dan transfer pengalaman mengatasi persoalan umat. Ketidakjelasan akad kerjasama akan menimbulkan masalah pada tataran praksisnya.

4) Menetapkan tahapan dan target pencapaian. Pada keempat kisah merepresentasikan tahapan 4 tahapan dakwah :Dakwah sirriyah, dakwah jahriyyah jamahiriyyah, konsolidasi dakwah dan keterakhir pengokohan eksistensi dan ekspansi dakwah. Pencapaian dakwah tidak akan mampu mencapai tahap akhir tanpa ada jihad (kerja optimal) dari para aktifis dakwah dan kerjasama semesta antar semua komponen masyarakat. Nabi Muhammad saw. berjihad mengembangkan dakwah dengan didukung oleh sahabat-sahabatnya yang setia dari kaum Muhajirin dan Anshar sehingga mampu melewati keempat fase dakwah ini.

5) Mendahulukan prinsip prenventif sebelum kuratif. Khidir as.tidak berkonsultasi dengan Nabi Musa as. dalam mengatasi berbagai persoalan umatnya karena ada yang mendesak untuk dicegah sebelum terjadi hal yang membahayakan seperti, melubangi perahu yang bagus milik orang miskin karena ada penguasa yang dzalim dan suka merampas perahu yang bagus-bagus. Khidir as 
dihadapkan pada dua persoalan yang tidak nyaman, melubangi perahu atau perahu dirampas. Pada kondisi seperti ini, ia cepat mengambil keputusan mengedapankan yang lebih sedikit resikonya yaitu, melubangi perahu sehingga nampak catat dan tidak dirampas sang raja yang dzalim. Andaikata ia tidak melubangi perahu dan keburu dirampas sang raja. maka para pelaut miskin itu akan kehilangan mata pencahariannya selamanya, sementara dengan dilubanginya, mereka akan bertahan menjalankan profesinya walau pun hanya dengan perahu yang cacat. ${ }^{9}$

6) Keempat kisah memuat aktivitas manusia yang aktif dan optimis. Ashab al-Kahfi meninggalkan rumah-rumah mereka menuju gua, teman Ashab al-Jannatain menasihati saudara yang kafir terhadap nikmat-nikmat Allah, Nabi Musa as. musafir untuk menuntut ilmu dan Dzulqarnain melalukan perjalanan ketiga tempat untuk menyebarkan dakwah tauhid. Aktivitas ini menunjukkan bahwa untuk menghindari fitnah harus dilakukan dengan aktivitas dan gerakan riil serta sikap optimis, bukan dengan berdiam diri, pasif dan menyerah. ${ }^{10}$

\section{Kesimpulan}

Dari pembahasan di atas, dapat ditarik kesimpulan berikut:

1. Kisah-Kisah Surat al-Kahfi merepresentasikan periode dakwah yang berkelanjutan; dari periode dakwah yang ketat dan tertutup, terbuka, konsolidasi dan pengokohan/kultural, tamkin (dakwah struktural) yang mampu melakukan ekspansi dakwah, dan perubahan dari yang tidak baik menjadi baik, dan dari baik menjadi lebih baik.

2. Masing-masing periode dakwah memiliki problem dan Allah SWT. dengan rahmat-Nya menyiapkan para da'i yang memiliki kapabilitas dan kapasitas yang mampu menghadapinya dengan menghadirkan aktivitas riil, gerakan terencana, komunikasi efektif dan manajemen dakwah yang rapi.

9 Rafiq Yunus al-Misri, al-I'jaz al-iqtishadi fi al-Qur'an, ( Beirut , Dar alSyamiyah,2005), hlm.,52-54

${ }^{10}$ Ali bin Muhammad Hamud, Jamaliyatu al-Tarabuth fi Qashashi al-kahfi, pdf, tt. hlm.,80. 
3. Metode dialog dengan segala variasinya merupakan metode yang cocok untuk semua periode dakwah dan segmen mitra dakwah dengan level intelektualitasnya yang berbeda.

4. Kontribusi seluruh komponen masyarakat dengan berbagai keahlian dan profesi dalam aktivitas dakwah sangat dibutuhkan, karena dakwah memerlukan variasi ilmu dan keahlian untuk mengelola aktivitas dakwah dan proses akselerasinya.

5. Pemuda sepanjang sejarahnya merupakan ujung tombak dakwah dan agen perubahan serta pelopor kebangkitan.

\section{Daftar Pustaka}

Bayanuni, Muhammad Abul Fatah, al-,Madkhal ila ilmi al-dakwah, Beirut:

Muassasah al-Risalah, 1995.

Biqa'i,Burhanuddin al-, Nadzmu al-Durar fi Tanasubi al-Ayat wa al-Suwar,

Beirut: Dar al-Kutub al-Ilmiyah, 1995.

Buthi, Muhammad Sa'id Ramadhan al-Buthi,Fiqhu al-Sirah, Beirut: Dar alFikr, 1979.

Ghazali,Muhammad al-Ghazali,Ma'a Allahi,Dirasat fi al-Dakwah wa alDu'at, Cairo: Dar al-Kutub al-Islamiyah, 1981.

Islahi,Amien Ahsan, Metode Dakwah Menuju Allah;: Jakarta, Litera Antarnusa, (terj.Mudzakkir cs), 1984.

Jabir, Husain bin Muhammad Ali ,al-Thariq ila Jamaati al-Muslimin,Cairo: Dar al-Wafa',1987, 1987.

Juraisyah, Ali Muhammad Ali , al-Takhthith li al-Dakwah al-Islamiyah,

Makkah al-Mukarramah: Rabithah al-Alam al-Islami, $1401 \mathrm{H}$.

Kafi, Jamaluddin ,Psikiologi Dakwah,Surabaya: Indah, 1993.

Maidani, Abdurrahman Habannakah al,,Fiqh al-Dakwah, Damaskus:Dar alQalam,1966.

Misri, Rafiq Yunus,al , al-I'jaz al-Iqtishadi Li al-Qur'an al-Karim,Beirut: Dar al-Syamiyah, 2005.

Musa, Abdullah bin Muhammad Alu, Asbab Najahi al-Dakwah fi al-Ahdi alNabawi,Riyadh: 1985. 
Nasr, Sayyed Vali, Maududi and The Making of Islamic Revivalisme,London: Oxford University press, 1996.

Qurthubi, Muhammad Ibn Ubai al-,,al-Jami' li Ahkam al-Qur'an,Beirut: Dar al-Kutub, 1945

Quthub,Sayyid ,Fi Dzilal al-Qur'an, Beirut: Dar al-Syuruq,1985.

Rafi' ah,Ummi,al-Muhassinat al-Lafdhiyyah wa al-Maknawiyyah fi Surati al-Kahfi, Malang: al-jami'ah al-Islamiyyah al-Hukumiyyah Malanj, 2007

Siba'i,Mushthafa al-Siba'i,al-Sirah al-Nabawiyah, Unisco: al-ittihad alAlami li al-Munadhdhamat al-Thullabiyah, 1985.

Sa'ad,Ma'ruf,al-Qiyam al-Tarbawiyyah fi Surati al-Kahfi Dirasah Tahliliyyah Maqasidiyyah, Marocco: Universitie Abo Bakar Belkaid, 2013.

Sulaiman,Yusuf,al-Wasfu fi Qashashi Surati al-Kahfi Dirasah Tahliliyyah, Malaysia: Majallah Kuliyyati al-'Ulum al-Islamiyyah,vol.8, 2013.

Syaukani, Muhammad Ibn Ali al-,Fath al-Qadir,Cairo:Maktabah alHalabi, 1964.

Waqi'ullah,Muhammad Shaleh, Tsaqafah al-Da'iyah wa Atsruha fi alDakwah, Marokko: Jami'ah al-Rabath al-Wathani, 2015.

Yakan, Fathi ,Musykilat al-Dakwah wa al-Da'iyah, Beirut: Muassasaah alRisalah, 1987.

Zuhaili, Wahbah al-,al-Tafsir al-Munir, Beirut:Dar al-Fikr,1991Abdul Karim Zaidan,Abdul Karim, Ushul al-Dakwah,Beirut, Muassasah alRisalah, 1987, Dhiya',1985. 